\title{
A EDUCAÇÃO INFANTIL EM PORTO VELHO/RO DO SÉCULO XX: HISTÓRIA E MEMÓRIA
}

\author{
Juracy Machado Pacífico ${ }^{1}$ \\ Marco Antônio de Oliveira Gomes ${ }^{2}$ \\ UNIR
}

\section{RESUMO}

O estudo objetiva construir um retrospecto histórico do atendimento à educação infantil no início da colonização do Estado de Rondônia, com recorte para o atendimento à Educação Infantil em Porto Velho/RO. Utiliza-se para isso de fontes bibliográficas, documentais e orais. Como fonte bibliográfica trabalha com pesquisas desenvolvidas sobre a povoação do Estado de Rondônia; como fonte documental apoia-se em informações disponíveis no site do Instituto Nacional de Estudos e Pesquisas Educacionais Anísio Teixeira (INEP); compuseram as fontes orais relatos de professoras que no período de 1965 a 1998 ocuparam funções na área técnico-pedagógica e docência na educação infantil no âmbito das secretarias municipal e estadual de educação. Os resultados apontam que o período anterior aos anos de 1990 foi marcado pela quase ausência quantitativa e qualitativa de atendimento formal às crianças menores de sete anos. No início dos anos de 1990 constatou-se a presença de iniciativas de ampliação do atendimento, mas no início do século XXI, em lugar de continuar com a política de ampliação ou, no mínimo, de manutenção, houve um retrocesso no atendimento em razão, principalmente, do novo modelo de financiamento do ensino fundamental instituído pelo FUNDEF, em 1996.

Palavras-Chave: Educação Infantil; Escolarização; Rondônia.

\section{CHILD EDUCATION IN PORTO VELHO/RO OF THE TWENTIETH CENTURY: HISTORY AND MEMORY}

\begin{abstract}
The study aims to build a historical retrospect of care to child education in the early colonization of Rondônia State, with a cutout for the care of Children's Education in Porto Velho / RO. We use to this work literature, documentary and oral sources. As bibliographic source works with research conducted on the population of the Rondônia state and as a documental source it is based on information available on the website of the InstitutoNacional de Estudos e PesquisasEducacionaisAnísio Teixeira(INEP). It was composed by oral sources reported from teachers in the period of 1965 to 1998 that occupied positions in technical and pedagogical and teaching in child education within the city and state departments of education. The results showed that the period prior to the 1990s was marked by the virtual absence of quantitative and qualitative formal service to children under seven years old. In the early 1990s it was found the presence of initiatives to expand the service, but at the beginning of this century, instead of continuing with the policy of enlargement or at least maintenance, it had a break in this service, especially because of the new funding model of the elementary school established by FUNDEF in 1996.
\end{abstract}

Keywords: Child education; Schooling;Rondônia. 


\section{INTRODUÇÃO}

Vários autores e autoras ${ }^{3}$ têm abordado aspectos da história geral e da história da educação em Rondônia. Alguns são mais abrangentes, outros estudam um município em específico ou, ainda, algum aspecto bem delimitado, mas todos e todas contribuindo significativamente para o registro histórico da educação no Estado.

No intuito de reunir informações com vistas à sistematização de dados que auxiliassem na análise das políticas públicas de atendimento à Educação Infantil em Porto Velho ${ }^{4}$ levantamos informações sobre aspectos históricos da constituição da educação infantil no Estado de Rondônia compreendendo o período iniciado em 1943 - quando foi criado o Território Federal do Guaporé - até o início da primeira década do século XXI, quando o Território já havia sido transformado em Estado de Rondônia, bem como já havia sido promulgada a Constituição do Estado de Rondônia (1989) e aprovada a Lei Orgânica do Município de Porto Velho (1990).

O objetivo deste texto foi construir um retrospecto histórico das ações voltadas para o atendimento à Educação Infantil no início da colonização do Estado de Rondônia, com recorte para o atendimento à Educação Infantil em Porto Velho.

Como fonte de dados utilizamos informações de pesquisas já desenvolvidas e do Instituto Nacional de Estudos e Pesquisas Educacionais Anísio Teixeira e buscamos informações em fontes orais, por meio de relatos das professoras Elmeri Borges de Lima, Terezinha Nina Paes e Josélia Gomes Neves. As duas primeiras, além de terem exercido a docência nesse período, ocuparam funções na área técnico-pedagógica na Divisão de Ensino Pré-Escolar da Secretaria de Educação do Território Federal de Rondônia (posteriormente Estado de Rondônia), e Josélia Gomes Neves, que também exerceu a docência na Educação Infantil, atuou junto à Divisão de Educação Pré-Escolar da Secretaria Municipal de Educação (SEMED) de Porto Velho.

Entendemos que todo esse conjunto de documentos expressos em pesquisas anteriores, ao lado de memórias de sujeitos que vivenciaram a determinados momentos da história, permitem a compreensão de um determinado objeto histórico, que não pode ser desvinculado das relações materiais socialmente produzidas.

As pesquisas realizadas por meio da história oral são adotadas como fontes para a compreensão do passado, ao lado outros documentos escritos, imagens e demais tipos de registro. Isto posto, cabe a ressalva que nem os documentos ou as falas das entrevistadas falam por si só, mas dependem fundamentalmente das questões levantadas pelos pesquisadores regionais. Dessa forma, os depoimentos articulam-se com outras fontes. Vejamos os apontamentos de Decca sobre o tema:

Os documentos como alguns já disseram, não falam por si, os historiadores obrigam que eles falem, inclusive, a respeito de seus próprios silêncios. E para realizar tal procedimento, utilizamo-nos de teorias e de procedimentos metodológicos que são, por sua vez, lugares de linguagem, modos de narratividade (DECCA, 1998, p. 23).

Não há como negar a possibilidade da história oral de trazer à tona informações valiosas sobre como as ações do Estado refletem no "chão da escola", apresentando seus desdobramentos nas práticas educativas, etc.

Com Kuhlmann Jr. (1998, p. 13) entendemos que,

[...] o estudo do passado pode, sim, suscitar reflexões que sirvam para aqueles que trabalham com a infância e sua educação nos dias de hoje, 
contribuindo para a sua formação e aprimoramento profissional. É mostrar que as propostas para o agora não podem ser pensadas como coelhos a se tirar magicamente da cartola, mas precisam envolver uma profunda reflexão ancorada tanto na prática quanto nos resultados das pesquisas e na produção teórica.

A história do Município de Porto Velho confunde-se com o início da história do próprio Estado, já que foi ele o palco de "desenvolvimento" inicial do, hoje, Estado de Rondônia. Este tem em sua memória muitas histórias construídas. Histórias que vão do horror e trágico - entre outras, como aquelas ligadas à construção da Estrada de Ferro Madeira-Mamoré; à devastação das florestas e assassinato dos povos indígenas; desumanização do ser humano e destruição do espaço natural em virtude dos garimpos, e; os conflitos e massacres na luta dos pequenos agricultores pela terra - até as conquistas como a resistência e luta dos, também, povos indígenas pelos seus direitos e pela manutenção de suas culturas e a luta incessante dos migrantes por vida e dignidade.

Assim, para o registro da história do atendimento às crianças da etapa da educação infantil teremos que iniciar pelo atendimento à essa etapa pelo Território Federal de Rondônia que depois transformou-se em Estado de Rondônia, incluindo nesse processo o município de Porto Velho, sendo este o foco desse estudo.

\section{REGISTROS DOCUMENTADOS: RETRATO DA EDUCAÇÃO INFANTIL EM PORTO VELHO DO SECULO XX}

No final do século XIX e início do século XX a infância e a sua educação integraram os discursos sobre a edificação dessa sociedade. As primeiras instituições préescolares assistencialistas no Brasil foram implantadas durante as duas décadas iniciais do século XX. A recomendação da criação de creches junto às indústrias ocorria com frequência nos congressos que abordaram a assistência à infância, como medida defendida no quadro da necessidade de criação de uma regulamentação das relações de trabalho, particularmente quanto ao trabalho feminino. (KUHLMANN Jr., 1998). Nesse período, não havia uma legislação trabalhista que regulasse a relação entre capital e trabalho. As longas jornadas de trabalho, os abusos patronais, e a exploração da mão de obra feminina e infantil eram uma constante. Por outro lado, foi possível observar na ação de alguns empresários a "preocupação" com a preservação do trabalhador como estratégia de ampliação da produtividade.

Rondônia também traz em sua história um pouco desse percurso, embora tardio. Das três primeiras décadas do século XX não se encontram registros de educação escolar voltada para as crianças menores de sete anos. É somente a partir de 1930, com a iniciativa privada, que podemos falar em educação escolar para as crianças até seis anos de idade. Percebe-se, no entanto, que as ações no âmbito da iniciativa privada pertenceram fundamentalmente à Igreja Católica. Para os intelectuais católicos, a defesa da escola pública pelos liberais não significava apenas uma forte ameaça à influência que ela detinha no campo educacional, mas principalmente o comprometimento de sua primazia no campo religioso e espiritual.

Como no início do século as terras que hoje são de Rondônia pertenciam aos Estados do Amazonas e Mato Grosso a educação nas localidades de Santo Antônio, Porto Velho, Guajará-Mirim ${ }^{5} \mathrm{e}$ demais povoados estavam sob a responsabilidade daqueles Estados. No entanto, o atendimento e acompanhamento eram precários e as justificativas para o descuido por parte do poder público pautavam-se na distância e no difícil acesso à 
região. Assim, enquanto o Estado se ausentava ou não assumia a educação das crianças da primeira infância a igreja acabava assumindo minimamente essa tarefa, garantindo seu domínio e ideologia.

A primeira escola criada em Rondônia data do ano de 1913, construída na localidade de Santo Antônio, a sete quilômetros de Porto Velho. Até então, mesmo com a existência de crianças, filhos e filhas dos seringueiros, seringueiras e de imigrantes que vieram para a construção da Estrada de Ferro Madeira-Mamoré, o poder público, neste caso dos Estados de Mato Grosso e Amazonas, estava completamente alheio a tal aspecto. (LIMA, 1987).

Em 1915 foi criada a primeira escola pública em Porto Velho, denominada de Escola Mista Municipal (LIMA, 1987), mas a educação pública oferecida ficava muito aquém da necessidade da população em idade escolar. Isso mostra que o processo ocupacional do Estado Rondônia não foi devidamente planejado com ações sociais em geral, e educacionais em especial. Porém, com a quase completa ausência de políticas públicas voltadas para o atendimento à educação escolar, a educação religiosa, aos poucos, foi ocupando os espaços.

Com a criação do Território Federal do Guaporé em 1943, em um momento marcado pelas transformações ocorridas na Era Vargas, a educação escolar torna-se alvo de preocupações do Estado brasileiro. Esse movimento não esteve ausente no recém-criado Território Federal. Visando organizar os serviços públicos locais, o governador, em 25 de fevereiro de 1944, criou o Departamento de Educação e, através do Decreto Territorial n. 13, de 10 de abril do mesmo ano, aprovou seu regimento, mas que foi alterado no ano seguinte, pelo Decreto-lei Federal n ${ }^{\circ}$. 7.772.

Desta forma, o órgão responsável pela organização do Sistema de Ensino do Território Federal do Guaporé, o Departamento de Educação, passou a se chamar Divisão de Educação, e um novo regimento foi aprovado em 1948. (GOMES, 2007) ${ }^{6}$.

Foram criadas várias escolas particulares na primeira metade do século $\mathrm{XX}$, porém tiveram curta existência, pois a desvalorização da borracha no mercado internacional levou a Amazônia a enfrentar uma forte crise, cuja consequência foi o abandono da região.

Conforme informações de Lima (1998), um Ofício n 145, de 10 de abril de 1946 informava que em 1945 havia 27 escolas Públicas no Território Federal do Guaporé e atendiam um total de 1.240 alunos. Dos estabelecimentos criados até meados do século, mantiveram-se funcionando as escolas Salesianas, o Instituto Nossa Senhora do Calvário, e uma instituição pública, o Grupo Escolar Estadual Barão de Solimões.

Segundo Vitor Hugo (1991), no início do século XX as crianças, adolescentes e jovens, cujos pais eram de "alta categoria" (pessoas com maiores condições financeiras) saiam para estudar fora do território, em outros países ou no Rio de Janeiro e Manaus, por exemplo. Por essa razão, a educação ficava por conta da iniciativa privada e da Igreja Católica. Segundo o autor, as escolas públicas, as poucas existentes, "eram puras ficções", pois os alunos e alunas faltavam muito às aulas. Havia uma reclamação geral sobre essa questão. No entanto, diz ele, se os alunos faltavam muito - "oscilavam de modo pavoroso"-, "[...] as professoras eram as primeiras a dar o exemplo de faltas contínuas, com pouca ou nenhuma atenção à sua missão". (HUGO, 1991, p. 21).

Inferimos que a precariedade estava tanto na falta de escolas como nas condições físicas e pedagógicas daquelas existentes, além das condições materiais de existência dos trabalhadores da região, incluindo-se, no rol das faltas, o problema da falta de pessoas habilitadas para o trabalho docente, já que a primeira turma formada na região foi a do Instituto Nossa Senhora do Calvário, iniciada em 1930 por Francisco Xavier Rey (Primeiro Bispo da Prelazia). 
A primeira instituição a atender crianças menores de sete anos de que se tem registro foi o Colégio Nossa Senhora Maria Auxiliadora que em 1930 começou a funcionar e a oferecer o Ensino primário - $1^{\mathrm{a}}$ à $4^{\mathrm{a}}$-, alfabetização (chamado de preliminar) e o Jardim de Infância, entre outras modalidades.

Destacamos na pesquisa realizada por Gomes (2007, p. 82) que em 1944 havia três unidades escolares no recém criado Território Federal do Guaporé, localizadas no município de Porto Velho, que ofereciam educação pré-primária (como era chamado o atendimento às crianças menores de sete anos), sendo que uma delas era pública e duas eram da iniciativa privada.

O Curso Normal Regional Carmela Dutra, iniciado em 1947, oferecia o ensino correspondente ao Primeiro Ciclo do Curso Normal e tinha também, como anexo para demonstração de práticas de ensino, um Jardim da infância. Além destes, em 1940 o Instituto Nossa Senhora do Calvário, criado pelo Bispo Dom Xavier Rey, em GuajaráMirim, atendia meninas de 7 a 14 anos, moradoras do Vale do Guaporé, mas também havia crianças de 6 anos, conforme relato e caso de Izabel Oliveira de Assunção (GOMES, 2007). Mesmo o instituto não sendo específico e habilitado para o atendimento à préescola, atendeu crianças menores de sete anos.

Já mais próximo do final da década de 1940 tem-se o registro de que no Grupo Escolar Barão de Solimões, público, foi instalado o Jardim de Infância, em 12 de abril de 1949, pelo Governador Joaquim de Araújo Lima. Estes são, até então, os únicos registros que se tem de atendimento às crianças pequenas até meados do século passado.

No entanto, o documento Diretrizes para a Educação Infantil - Estrutura, Organização e Funcionamento, elaborado em 1997 pela Secretaria de Educação do Estado de Rondônia (SEDUC), registra que em Rondônia o início do atendimento à Educação Infantil pública data dos anos de 1950, quando foram criados dois Jardins de Infância públicos: o Jardim de Infância Central, no centro da cidade, que atendia cerca de 200 crianças na faixa de 4 a 6 anos, mas que funcionou durante poucos anos; o Jardim de Infância Murilo Braga, criado em 1957, passando posteriormente a funcionar como escola de Ensino Fundamental (na época primário, $1^{\mathrm{a}}$ a $4^{\mathrm{a}}$ série).

Observa-se que, se até a década de 1950 o atendimento às crianças menores de sete anos praticamente inexistiu, tal realidade não foi diferente nas duas décadas seguintes, conforme se pode observar nos quadros 1e 2. Seria até destoante, com o olhar de hoje, falar em qualidade da educação naquela época, já que a precariedade era total.

Quadro 1: № de escolas que atendiam à educação infantil Estado de Rondônia - 1944 a 1998.

\begin{tabular}{|c|c|c|c|c|c|c|c|c|c|c|}
\hline \multicolumn{11}{|c|}{ Estado de Rondônia - 1944 a 1998} \\
\hline \multicolumn{11}{|c|}{ Educação Infantil* - Unidades Escolares } \\
\hline & \multicolumn{2}{|c|}{ Total } & \multicolumn{2}{|c|}{ Federal } & \multicolumn{2}{|c|}{ Estadual } & \multicolumn{2}{|c|}{ Municipal } & \multicolumn{2}{|c|}{ Particular } \\
\hline ANO & Total & Campo & Total & Campo & Total & Campo & Total & Campo & Total & Campo \\
\hline 1944 & 3 & - & 1 & - & - & - & - & - & 2 & - \\
\hline 1946 & 3 & - & - & - & - & - & - & - & - & - \\
\hline 1955 & 5 & - & - & - & 2 & - & - & - & 3 & - \\
\hline 1972 & 3 & - & 2 & - & - & - & - & - & 1 & - \\
\hline 1973 & 5 & - & 4 & - & - & - & - & - & 1 & - \\
\hline 1976 & 7 & - & 2 & - & - & - & - & - & 5 & - \\
\hline 1977 & 8 & - & 2 & - & - & - & - & - & 6 & - \\
\hline 1978 & 20 & - & 4 & - & - & - & - & - & 16 & - \\
\hline 1979 & 25 & - & 5 & - & - & - & - & - & 20 & - \\
\hline 1980 & 36 & - & 5 & - & - & - & 7 & - & 24 & - \\
\hline
\end{tabular}




\begin{tabular}{|c|c|c|c|c|c|c|c|c|c|c|}
1981 & 56 & - & - & - & - & - & 33 & - & 26 & - \\
\hline 1982 & 103 & - & - & - & - & - & 60 & - & 43 & - \\
\hline 1983 & 97 & - & - & - & - & - & 76 & - & 21 & - \\
\hline 1984 & 127 & - & 2 & - & - & - & 99 & - & 26 & - \\
\hline 1988 & 224 & 56 & 1 & - & 51 & 5 & 129 & 48 & 43 & 3 \\
\hline 1989 & 276 & 72 & - & - & 149 & 16 & 78 & 51 & 49 & 5 \\
\hline 1991 & 303 & 70 & 1 & - & 167 & 34 & 72 & 33 & 63 & 3 \\
\hline 1992 & 484 & 140 & - & - & 199 & 23 & 201 & 114 & 84 & 3 \\
\hline 1993 & 405 & 60 & - & - & 200 & 21 & 130 & 36 & 75 & 3 \\
\hline 1994 & 454 & - & 1 & - & 202 & - & 161 & - & 90 & - \\
\hline 1995 & 495 & - & 3 & - & 201 & - & 179 & - & 112 & - \\
\hline 1996 & 491 & - & 7 & - & 200 & - & 167 & - & 117 & - \\
\hline 1997 & 496 & - & - & 33 & 194 & 61 & 173 & 2 & 129 & - \\
\hline 1998 & 459 & - & - & 23 & 148 & 56 & 160 & 4 & 151 & - \\
\hline
\end{tabular}

Fonte: Organizado pela autora com dados do Censo INEP - 1946 a 1999.

*Observações sobre a nomenclatura:até 1955 - Pré-primário Infantil; de 1971 até 1996 - até 3 anos = Maternal e Jardim; 4 a 6 = Pré-escola; a partir de 1997 - 0 a 6 = Educação Infantil (03 anos = Creche; 4 a $6=$ Pré-escola).

Os números apresentados nos informam o quantitativo de escolas em Rondônia. Não localizamos no censo os anos que não aparecem no quadro, de onde se infere que não houve registros sobre a educação infantil (pré-primário ou pré-escolar) nesse período por não haver, de fato, atendimento. Observa-se que de 1944 a 1972 o número de escolas é mínimo e quase totalmente da iniciativa privada.

De 1972 até 1979 ocorreu um tímido crescimento das escolas mantidas pelo Estado (União). Somente nos anos de 1980 é que vão aparecer escolas da rede municipal. Analisando a planilha pode-se inferir que as escolas que apareciam como federais provavelmente passaram para o gerenciamento da rede municipal, pois desapareceram do censo no ano em que o Território foi transformado em Estado. Houve, a partir de 1981, a ampliação do número de escolas que atendiam crianças menores de seis anos.

Veremos mais adiante, em depoimentos, que a grande maioria das escolas não era de educação infantil (ou pré-escolar), mas sim, escolas que atendiam turmas de crianças menores de 6 anos, muitas vezes nos chamados anexos da escola "X" ou "Y"7.

Mesmo não aparecendo no Censo, segundo Brasil (1994), em 1977 a Prefeitura do Município de Porto Velho criou a Pré-escola Municipal Saul Bennesby, na área urbana, no bairro Belvedere, que ainda hoje é bairro de periferia da Capital. No entanto, o Decreto Municipal de Criação desta escola data de 1991. Em 1993 foi ampliada e passou a ter mais de três salas de aula. Em 1994 passou a ter oito salas, o que a tornara uma das maiores escolas da Capital, e de todo o Estado de Rondônia, a oferecer exclusivamente Educação Pré-escolar.

A rede privada começou a ampliar o atendimento à Educação Infantil desde 1978, fato revelador da omissão do Estado no provimento de recursos para criação e manutenção das escolas no Território de Rondônia. Em 1977 havia seis escolas e em 1978 saltam para 16 escolas da rede privada, conforme mostram os dados do censo do INEP, no quadro 1.

É interessante observar que em 1980, quando a região ainda era Território, aparecem somente 12 escolas públicas, mas esse número salta para 33 no ano seguinte. No primeiro ano de Estado, 1982, esse número salta para 60, todas contabilizadas como municipais, embora haja registros de que algumas escolas eram da rede Estadual.

O quadro 2, a seguir, apresenta o número de crianças na faixa de 0 a três anos matriculadas na educação infantil (pré-escolar) no mesmo período de 1944 a 1998 no Estado de Rondônia. 
Segundo as Diretrizes/SEDUC (RONDÔNIA, 1997), no período de 1960 a 1972 o então Território retirou-se desse atendimento, sendo este realizado apenas pela iniciativa privada, voltando a atender crianças menores de sete anos somente em 1972, o que pode ser observado pelos dados do quadro 2.

A partir de 1955 até o ano de 1971 não localizamos no censo qualquer registro sobre educação infantil. Vejamos os dados de matrícula referentes ao período de 1944 a 1998:

Quadro 2: Matrícula na educação infantil - Estado de Rondônia - 1944 a 1998.

\begin{tabular}{|c|c|c|c|c|c|c|c|c|c|c|}
\hline \multicolumn{11}{|c|}{ Estado de Rondônia - 1944 a 1998} \\
\hline \multicolumn{11}{|c|}{ Matrícula na Educação Infantil* no início do ano, segundo a dependência administrativa } \\
\hline & \multicolumn{2}{|c|}{ Total } & \multicolumn{2}{|c|}{ Federal } & \multicolumn{2}{|c|}{ Estadual } & \multicolumn{2}{|c|}{ Municipal } & \multicolumn{2}{|c|}{ Particular } \\
\hline & Total & Campo & Total & Campo & Total & Campo & Total & Campo & Total & Campo \\
\hline 1944 & 266 & - & - & - & - & - & - & - & - & - \\
\hline 1946 & 175 & - & - & - & - & - & - & - & - & - \\
\hline 1955 & 549 & - & - & - & 397 & - & - & - & 152 & - \\
\hline 1971 & 70 & - & - & - & - & - & - & - & 70 & - \\
\hline 1972 & 334 & - & 287 & - & - & - & - & - & 47 & - \\
\hline 1973 & 700 & - & 598 & - & - & - & - & - & 102 & - \\
\hline 1974 & 1100 & - & 475 & - & - & - & - & - & 625 & - \\
\hline 1975 & 655 & - & 239 & - & - & - & - & - & 416 & - \\
\hline 1976 & 750 & - & 385 & - & - & - & - & - & 365 & - \\
\hline 1977 & 883 & - & 466 & - & - & - & - & - & 417 & - \\
\hline 1978 & 1919 & - & 554 & - & - & - & - & - & 1365 & - \\
\hline 1979 & 2677 & - & 830 & - & - & - & - & - & 1847 & - \\
\hline 1980 & 3713 & - & 847 & - & - & - & 287 & - & 2579 & - \\
\hline 1981 & 5289 & - & - & - & - & - & 2512 & - & 2777 & - \\
\hline 1982 & 11056 & - & - & - & - & - & 5829 & - & 5227 & - \\
\hline 1983 & 12345 & - & - & - & - & - & 9791 & - & 2554 & - \\
\hline 1984 & 15518 & - & 445 & - & - & - & 11975 & - & 3098 & - \\
\hline 1989 & 23202 & 1854 & - & - & 13467 & 530 & 3513 & 1067 & 6222 & 257 \\
\hline 1991 & 23103 & 2039 & 20 & - & 13214 & 1086 & 4246 & 605 & 5623 & 348 \\
\hline 1992 & 33407 & 3632 & - & - & 15784 & 929 & 10820 & 2256 & 6803 & 447 \\
\hline 1993 & 30866 & 1538 & - & - & 15881 & 506 & 9316 & 664 & 5669 & 368 \\
\hline 1994 & 34912 & 2102 & 28 & - & 16097 & 958 & 11439 & 800 & 7348 & 344 \\
\hline 1995 & 38462 & 283 & 45 & 45 & 14562 & 906 & 14370 & 829 & 9485 & 503 \\
\hline 1996 & 32693 & 2168 & 76 & 40 & 14445 & 1095 & 11779 & 911 & 6393 & 122 \\
\hline 1997 & 33206 & 2069 & - & - & 13930 & 799 & 12356 & 1170 & 6920 & 100 \\
\hline 1998 & 39758 & 2408 & - & - & 13007 & 616 & 14494 & 1183 & 12257 & 609 \\
\hline
\end{tabular}

Fonte: Organizado pela autora com dados do Censo INEP - 1946 a 1999.

*Observações sobre a nomenclatura: até 1955 - Pré-primário Infantil; de 1971 até 1996 - Até 3 anos = Maternal e Jardim; 4 a 6 = Pré-escola; a partir de 1997 - 0 a 6 = Educação Infantil (03 anos = Creche; 4 a $6=$ Pré-escola).

A educação infantil continuou a se expandir e outros órgãos também contribuíram nesse período com essa expansão do atendimento às crianças pequenas, dentre eles a Secretaria de Trabalho e Promoção Social (SETRAPS - extinta), com trabalho integrado à Secretaria de Estado da Educação. Para isso utilizavam dependências de Centros Comunitários para o atendimento nutricional, educacional, médico e odontológico às crianças. Observa-se que a preocupação era predominantemente assistencial. (RONDÔNIA, 1997). 
Sobre essa questão Kuhlmann Jr. (1998, p. 167) ressalta que se a primeira característica da educação assistencialista era a virtude pedagógica atribuída ao ato de se retirar a criança da rua, o segundo aspecto dessa proposta educacional era que a baixa qualidade do atendimento fazia parte dos seus objetivos: previa-se uma educação que preparasse as crianças pobres para o futuro que com maior probabilidade já lhes estaria destinado, ou seja, uma educação mais moral do que intelectual voltada para a profissionalização. Assim, à educação não caberia a emancipação e muito menos a mobilidade social, mas apenas livrar as crianças de meios considerados impróprios para o desenvolvimento moral das mesmas, e depois devolvê-las a esse mesmo meio social, o que conferia a intencionalidade de uma educação de baixa qualidade por parte do Estado.

Nesse sentido, o anacronismo da organização da escola pública punia os filhos da classe trabalhadora com a impossibilidade do acesso à escola, ou ainda, quando possuíam esse acesso, não havia condições materiais de ascender através da educação ao conhecimento culturalmente significativo.

Segundo um documento da Secretaria de Estado da Educação (SEDUC) (RONDÔNIA, 1997), em 1982 o Movimento Brasileiro de Alfabetização (MOBRAL) teve também participação ativa, apoiando as Secretarias Municipais de Educação e a Secretaria de Estado da Educação nos programas de Educação Pré-Escolar, através de ações complementares e suplementares direcionadas para a população de baixa renda.

O atendimento à educação infantil cresceu nos anos de 1980, porém impulsionado também pelas escolas comunitárias. No caso de Porto Velho, a expansão via escolas comunitárias ocorreu, principalmente, nos bairros mais afastados do centro da cidade, devido ao grande número de crianças em idade na faixa etária de 0 a 6 anos e ao pouco atendimento por parte da rede pública.

Temos, portanto, em nossa história da Educação Infantil da rede Municipal, evidências de que o que caracterizou o período que vai de 1930 a década de 1980, nacionalmente, conforme apontado por Kramer (1992) e Rosemberg (2003), também marcou presença em Rondônia: as ações assistencialistas e compensatórias promovidas pelo setor público.

Um aspecto interessante é que se observarmos o quadro 2, os números indicam que no período de 1981 a 1983 não houve atendimento à educação infantil pelas esferas federal e estadual. Talvez isso tenha relação com uma medida de descentralização implantada pelo Governo do Estado (apresentada nos próximos parágrafos deste texto), ou erro na organização dos dados. Mas alguns registros informam outros dados, o que pode ser observado no Relatório dos Encontros Regionais de Educação Pré-Escolar, elaborado pelo MEC em agosto de 1981, onde observamos que também o número de atendimentos deste ano não confere com os registros do INEP.

A Secretaria de Educação está dando todo o apoio necessário para a expansão da Educação Pré-Escolar no Território, a fim de oferecer esta oportunidade educacional às crianças na faixa etária de 4 a 6 anos. Atualmente são atendidas 7.469 crianças. Foram realizados 3 treinamentos de professores para a Pré-escola, sendo um em 1980 e dois em 1981; está programado um outro treinamento para os professores do Município, que deve ser realizado ainda no corrente ano. O objetivo destes treinamentos é atualizar e aperfeiçoar o pessoal docente.

A equipe de supervisão presta assistência técnico-pedagógica às Préescolas através de observações, reuniões e encontros pedagógicos, fornecendo subsídios para a melhoria do processo da Educação PréEscolar. A clientela da rede oficial e municipal é atendida [...] através do fornecimento de suplementação alimentar, com um cardápio variado, 
suprindo assim, carências nutricionais das crianças. (BRASIL, 1981, p. 64).

Dessa forma, o atendimento dos filhos e filhas da classe trabalhadora pela escola e melhoria da qualidade dos serviços escolares tem sido um artifício retórico no discurso oficial dos órgãos do Estado. Verifica-se, entre outras questões, a preocupação no "treinamento de professores"com vistas ao aperfeiçoamento do pessoal docente. Cabe enfatizar ainda, outros aspectos a serem destacados do texto acima. No quesito qualidade de ensino, evidenciada na utilização de indicadores qualitativos: quantidade de crianças atendidas e treinamento de professores. Dessa consideração emerge um questionamento importante: até que ponto esses aspectos devem ser considerados como indicadores de qualidade na educação escolar?

Em 1979, antes mesmo da promulgação da Constituição Federal de 1988, que no Artigo 211, § $2^{\circ}$ propõe a municipalização da Educação Infantil, o Estado de Rondônia já havia proposto essa forma de gerenciamento. De acordo com registros da antiga Secretaria Municipal de Educação e Cultura de Porto Velho-RO, em um livro produzido pela própria gráfica da Prefeitura, intitulado "Achegas para a história da Educação no Estado de Rondônia" (organizado pelo professor Abnael Machado de Lima, divulgado em 1987), o Governo do Estado passou para os municípios a responsabilidade pela Educação, via municipalização, conforme se verifica no texto da obra:

O ano de 1979 é um marco na história da educação em Rondônia. Com o objetivo de fortalecer e dotar de maior autonomia os municípios, bem como agilizar as soluções dos problemas educacionais locais, o governo municipalizou o ensino de $1^{\circ}$ grau, através do Decreto $n^{\circ} 1100 / 79$ e no seguinte ano exarava o Decreto $n^{\circ} 149 / 80$, municipalizando o ensino de $2^{\circ}$ grau. (LIMA, 1987).

O Decreto aponta a municipalização do ensino fundamental como estratégia para viabilizar aos municípios maior autonomia e o seu fortalecimento em consonância com a Constituição Federal em vigor (art. $15 \S 3^{\circ}$, alínea "f") e a Lei 5692/71 (art. 58). (TAMBORIL, 2000). É possível inferir que a intenção foi passar as responsabilidades com a educação, colocando-as a cargo dos municípios, porém estes não davam conta nem mesmo da educação infantil e do ensino fundamental (naquele momento o $1^{\circ}$ grau), quanto mais de ensino médio, que até hoje ainda não foi totalmente atendido, realidade evidenciada não só em Rondônia, mas em todo o país. Tamboril (2000, p. 28-29), ressalta que:

[...] neste mesmo Decreto o governo traz para si a responsabilidade de supervisionar, orientar, inspecionar as escolas dos sistemas municipais de educação, bem como o aperfeiçoamento e atualização dos professores(as) e especialistas. (art. $5^{\circ} \S$ único).

Em entrevista concedida a Tamboril (2000), José Álvaro Costa, que foi naquele ano Secretário Municipal de Educação de Porto Velho, lembra que:

[...] este foi o grande problema da municipalização, a interferência permanente do governo territorial (e depois estadual) nos rumos da educação no âmbito municipal. Além desse comando paralelo a diferença salarial entre os(as) professores(as) também dificultava o desenvolvimento das ações, já que havia no interior de uma mesma escola, professores(as) federais, estaduais e municipais, muitas vezes com diferenças salariais significativas. 
No entanto, anos depois acontece algo bem contraditório: quando a Constituição Federal de 1988 propunha uma indução à municipalização do ensino fundamental e municipaliza a educação infantil, o Estado revoga sua iniciativa, através do Decreto $\mathrm{n}^{\circ}$ 3816, de 28 de Junho de 1988. Desse momento em diante a Secretaria Municipal de Educação assume somente as escolas da rede municipal de ensino que já faziam parte do sistema antes da municipalização, em sua grande maioria, localizadas na zona rural, canalizando os seus recursos humanos e financeiros para o atendimento dos alunos $\mathrm{e}$ alunas matriculados e matriculadas nestas unidades escolares. (TAMBORIL, 2000).

$\mathrm{Na}$ Constituição Estadual de 1989 (texto original), em seu artigo Art. 192, o Estado propõe a descentralização do ensino:

O Estado adotará a descentralização do ensino, através da cooperação com os Municípios, obedecidas as seguintes diretrizes: I - atendimento prioritário à escolaridade obrigatória; II - garantia de repasse de recursos técnicos e financeiros; Parágrafo único. A cessão de pessoal do magistério para os sistemas municipais de ensino, quando houver, dar-seá com todos os direitos e vantagens funcionais do cargo.

A rede estadual começou então ampliar seu atendimento à Educação Infantil, e em 1989 já atendia 13.467 crianças, o que superava o atendimento da rede municipal e particular, pois no total foram atendidas, nesse ano, 23.202 crianças. Em 1995 o estado de Rondônia começou a se retirar e o número total de crianças atendidas no Estado também caiu, pois não houve, a partir dessa data, expansão de matrículas, nem por parte das municipalidades e nem por parte da rede privada. Se em 1995 o total de crianças atendidas no Estado era de 38.462, em 1998 já eram apenas 31.977 crianças atendidas.

O conjunto da legislação proposta a partir do final dos anos de $1980^{8}$ foi, sem dúvida, o mais significativo para a educação brasileira. Tal significância refere-se tanto às modificações produzidas - que atingiram basicamente todos os setores da educação - na estruturação do sistema nacional, e na garantia de direitos, quanto às possibilidades deixadas para os sistemas promoverem alterações em suas estruturas e formas de organização. Em se tratando da Educação Infantil, esta é declarada como direito das crianças e de suas famílias e dever do Estado no artigo 208 da Constituição Federal de 1988, e, seguidamente, no artigo $4^{\circ}$ da Lei de Diretrizes e Bases da Educação Nacional (LDB) $n^{\circ}$ 9394/1996.

\section{MEMÓRIAS: REGISTROS DE RELATOS ORAIS}

Apresentamos o histórico da educação infantil em Porto Velho elaborado com o auxílio de relatos orais de três professoras, pedagogas, que desenvolveram trabalhos na área da docência e coordenação da etapa da Educação Infantil em Porto Velho no âmbito da SEDUC e da SEMED. Os relatos foram fundamentais para o registro de informações, no todo ou em parte, não localizadas em fontes documentais. Portanto, relatos e documentos tiveram o objetivo de contribuir com o registro histórico do atendimento à educação infantil em Porto Velho. O conteúdo dos relatos foi identificado indicando-se, com a devida autorização, o nome das colaboradoras: Profa. Elmeri, Profa. Josélia e Profa. Terezinha Nina. Suas memórias servem de subsídios para compreensão da história da educação infantil em Rondônia, e mais especificamente, de Porto Velho.

Ressaltamos, porém, que o movimento de compreensão dos determinantes históricos na história o atendimento à educação infantil levou-nos a retomar aspectos importantes da história do Estado de Rondônia e do Município de Porto Velho, que 
atravessou diferentes ciclos econômicos oriundos das necessidades materiais impostas pelo capital.

Quanto aos ciclos, verifica-se que os períodos de expansão econômica na região impulsionou a chegada de imigrantes no Estado. Hoje, já avançados alguns anos do século XXI, temos a construção das usinas hidrelétricas do Rio Madeira. As características e motivações que levam o Estado a investir na construção das hidrelétricas obedecem a lógica expansionista do capital que destrói e constrói de acordo com seus interesses de reprodução. Sem dúvida, todas as etapas do desenvolvimento econômico percorridas pelo Estado trouxeram impactos na organização política, econômico e social. Não há como negar que a ilusão do progresso e da riqueza para os mais pobres atraiu um grande contingente de pessoas para o Estado de Rondônia, em especial para Porto Velho.

A Amazônia apresentava como potencial produtivo, nos primeiros tempos, o extrativismo vegetal e mineral: no vale do Madeira, a coleta de drogas do sertão (cacau nativo, canela, cravo, salsaparrilha, urucum, quina, anil, baunilha e óleo de copaíba) e no vale do Guaporé prevaleceu a extração do ouro e de produtos vegetais como as drogas do sertão, além da comercialização de indígenas como escravos. Os indígenas também representavam a principal mão-de-obra na coleta dos produtos vegetais da floresta, já que esta era por eles muito conhecida e os mesmos tinham grande habilidade para se deslocar no meio da vegetação.

Conforme Medeiros (2004), com o desenvolvimento alcançado no final do século XVIII e início do século XIX, com a revolução industrial e com ela o surgimento da máquina a vapor iniciou-se no Brasil a era da construção de ferrovias. Como uma das vias para se chegar a outras cidades da Amazônia era a fluvial, descendo os rios Guaporé, Mamoré, Madeira e Amazonas até a Cidade de Belém do Grão-Pará - neste percurso havia uma distância de $420 \mathrm{~km}$ com 20 cachoeiras -, em 1883 o governo brasileiro nomeou duas comissões para analisar a possibilidade de construção de uma ferrovia na região do rio Madeira.

Junte-se a este fato, o de que a Bolívia havia, em 1825, conquistado sua independência e passou a articular uma saída via Madeira-Amazonas que desse acesso ao Atlântico. A ideia era construir uma estrada de ferro que se desviasse do trecho das cachoeiras dos rios Mamoré e Madeira. Assim, em 1870 o Brasil assinou um tratado de relações comerciais e diplomáticas com a Bolívia no qual assumia o compromisso de construir uma ferrovia visando resolver a situação problemática enfrentada pelo transporte fluvial.

Em 28 de novembro de 1907, após duas frustradas tentativas de construção da ferrovia por parte da Bolívia, a empresa Madeira-Momoré Railway, por Percival Farquhar, recebe autorização do governo brasileiro para funcionar no Brasil.

Assim, após tantas tentativas e, mesmo com todas as dificuldades enfrentadas, em 30 de agosto de 1912 a obra da ferrovia foi concluída, com uma extensão de 366 quilômetros que ligava Porto Velho a Guajará-Mirim, esta situada no Vale do Mamoré, na fronteira com a Bolívia.

Em 1912, ano de conclusão da Estrada de Ferro Madeira-Mamoré, o Brasil alcançava a condição de maior exportador e produtor da borracha. Com a sua conclusão e com a perspectiva de crescimento local, em 2 de outubro de 1914 o governador do Estado do Amazonas, Jonathas de Freitas Pedrosa, sancionava a Lei $n^{\circ} 757$ que criava o Município de Porto Velho, sendo este pertencente ao Estado do Amazonas. O município foi oficialmente instalado em 24 de janeiro de 1915.

Porém, como a história não é linear, paralelamente ao investimento na EFMM com o objetivo de exportar a borracha da Amazônia, outros países, como a Malásia, investiam 
na produção de látex. Assim, logo após a conclusão da EFMM iniciava-se uma crise no comércio de exportação, com profundos reflexos na economia brasileira.

Em 1913 a borracha produzida na Amazônia começou a concorrer com novos produtos asiáticos (inclusive a borracha). O preço mundial da borracha caía para a quarta parte do valor. No ano de 1919, o Brasil, que havia usufruído do monopólio da borracha, abastecia apenas a oitava parte do consumo mundial. "Meio século depois, o país compra no estrangeiro mais da metade da borracha de que necessita". (GALEANO, 2005, p. 120).

O declínio do primeiro Ciclo da Borracha freou o avanço demográfico daquele período, que voltou a crescer a partir de meados do mesmo século (XX) com muito mais força, iniciando o denominado Segundo Ciclo da Borracha. Este teve início nos anos de 1940, quando, no período da Segunda Guerra Mundial, a borracha da Amazônia voltou a ocupar um novo lugar.

Os japoneses ocuparam a Malásia e as potências aliadas buscavam outras formas de se abastecer de borracha. Brasil e Estados Unidos haviam assinado o Tratado de Washington que visava, entre outros aspectos, a reativação dos seringais. (MEDEIROS, 2004).

Com o novo impulso da produção da borracha, com o aumento da população e com a necessidade de proteger as fronteiras do Brasil, o governo, estrategicamente, cuidou da criação do Território Federal do Guaporé, em 13 de setembro de 1943, que em 1956, passou a ter a denominação de Território Federal de Rondônia ${ }^{9}$.

Os anos de 1960 e 1970 ficaram marcados pelas construções de muitas estradas. Também nesse período Rondônia foi palco de vários projetos de assentamentos e aberturas de estradas, coordenados pelo Instituto Brasileiro de Reforma Agrária (IBRA), que posteriormente transformou-se em Instituto Nacional de Colonização e Reforma Agrária (INCRA).

Estaria efetivada a ação ocupacional nas áreas de fronteiras. De lá para cá transformações sociais, culturais, políticas, administrativas e econômicas continuaram acontecendo, o que culminou com a passagem, em 1981, de Território Federal de Rondônia para Estado de Rondônia, instalado no dia 04 de janeiro de 1982.

O Estado teve um crescimento populacional desenfreado, principalmente nos anos de 1970 e 1980, conforme se pode perceber no quadro 3:

Quadro 3: Evolução da taxa populacional do Estado de Rondônia no período de 1950 a 2007.

\begin{tabular}{|c|c|c|c|}
\hline Ano & $\begin{array}{c}\text { População } \\
\text { (Total) }\end{array}$ & $\begin{array}{c}\text { Cidade } \\
(\mathbf{\%})\end{array}$ & $\begin{array}{c}\text { Campo } \\
(\mathbf{\%})\end{array}$ \\
\hline 1950 & 36.935 & 37,40 & 62,60 \\
\hline 1960 & 69.792 & 43,26 & 56,74 \\
\hline 1970 & 111.064 & 53,63 & 46,37 \\
\hline 1980 & 491.069 & 46,54 & 53,46 \\
\hline 1991 & 1.132 .692 & 58,21 & 41,79 \\
\hline 1996 & 1.231 .007 & 62,00 & 38,00 \\
\hline 2007 & 1.453 .756 & 64,11 & 35,89 \\
\hline
\end{tabular}

Fonte: Censo demográfico 1940-1991. Rio de Janeiro: IBGE, 1950-1997; contagem da população 1996. Rio de Janeiro: IBGE, 1997. v.1: resultados relativos a sexo da população e situação. Contagem da população em 2007 (IBGE, 2008).

Esse crescimento populacional teve início em 1970, quando o governo brasileiro iniciou o Programa de Integração Nacional (PIN) que incluía um esquema de colonização para a Bacia Amazônica. À medida que a notícia dos assentamentos do INCRA e o acesso a solos considerados férteis em Rondônia se espalharam pelo país as taxas de imigração no 
território começaram a crescer, forçando o INCRA a acelerar o processo. Por volta de 1974 o INCRA já distribuía lotes a mais ou menos 4.000 famílias (DIEGUES, 1999, p. 101).

A aceleração da migração foi considerada, entre outros fatores, como consequência imediata do asfaltamento da Rodovia Porto Velho-Cuiabá e de outras estradas. Outro fator de migração foi a campanha feita pelo governo de Rondônia retratando o novo estado como o "El Dorado" na região Amazônica para agricultores sem-terra e outros tantos marginalizados da sociedade. Também outro fator considerado relevante para o aumento da migração foi a crise econômica atravessada pelo país em meados dos anos de 1980. Muitas pessoas das áreas urbanas das regiões do centro-sul migraram para Rondônia em busca de trabalho e com ilusão do ouro em garimpos recentemente descobertos, além de outras atividades agrícolas.

Em 1975 Rondônia, ainda território, contava com apenas dois municípios: Porto Velho e Guajará-Mirim. Naquele ano foram criados mais cinco: Cacoal, Ariquemes, JiParaná (inicialmente chamado de Rondônia), Pimenta Bueno e Vilhena, todos no eixo da BR-364. Até 1980 a imigração era predominantemente rural, mas a partir daquele ano começa a imigração urbana, e somente no primeiro semestre de 1982, migraram para Rondônia 12.679 pessoas das quais 21\% era do Estado do Paraná. (MEIRELES, 1983). Quando foi criado, em 1981, o Estado de Rondônia constituía-se de 13 municípios ${ }^{10}$. Em 2008 já são 52 municípios, alguns com população bem pequena, como é o caso de Pimenteiras do Oeste, com 2.358 habitantes, enquanto a Capital, Porto Velho, chega a 369.345 habitantes, mas a maioria dos municípios tem uma população entre 10.000 e 20.000 habitantes ${ }^{11}$.

\section{Relato 1 - Professora Terezinha Nina Paes}

A professora Terezinha Nina Paes, licenciada em Pedagogia pela Universidade Federal do Pará (UFPA), atuou na educação de Rondônia no período de 1965 até o ano de 1994, quando se aposentou. Concedeu-nos, em abril de 2010, um relato sobre a Educação Infantil em Rondônia.

Conta-nos a professora que em seus 29 anos de atuação na educação de Rondônia, foi professora de educação pré-escolar e primária no período de 1965 a 1979, momento em que atuou em várias escolas: Escola Territorial Marechal Malet, Escola São Domingos Sávio (Escola da Prelazia - Particular), e Escola Dom Bosco (4 ${ }^{\text {a }}$ série primária Particular). Atuou também como Técnica em Orientação e Supervisão Escolar no período de 1980 a 1985 e foi Diretora da Divisão de Ensino Pré-escolar no período de 1985 a 1994. Neste último período atuou também como Membro do Conselho Estadual de Educação de Rondônia (CEE/RO).

No período de 1972 (ano em que foi concursada) ao ano de 1980 atuou na Escola Municipal Padre Chiquinho e em 1980 foi trabalhar no Ex-Território Federal de Rondônia.

Seu relato foi, assim como os demais, muito importante para o registro histórico do atendimento à Educação Infantil em Porto Velho, o que nos fez colocá-lo quase na íntegra. A professora nos lembra que:

O crescimento populacional nas décadas de 1970 a 1980, em Rondônia, teve sérias repercussões no sistema Educacional, ocorrendo um aumento acentuado nos serviços de ensino.

$\mathrm{Na}$ área de Educação Infantil ou Pré-Escola de Porto Velho existia esse atendimento em algumas escolas, o que tornou necessário a elaboração de um Projeto de Política de Atendimento, assegurando acesso a um maior número de alunos com idade entre 4 a 6 anos. 
$\mathrm{Na}$ época, considerando que as crianças de médio e alto nível sócioeconômico eram favorecidas por uma estimulação de "Currículo Oculto" em virtude de sua convivência no meio sócio-cultural privilegiado, tinham acesso aos melhores Institutos Educacionais Infantis da época, todos particulares, tais como:

- Jardim de Infância Laura Vicunã;

- Jardim Dr. Granjeiro;

- Jardim Chapeuzinho Vermelho;

- Jardim Pequeno Céu;

- Jardim Carlos Costa;

- Jardim Menino Jesus - dentre outros. (Relato Profa. Teresinha Nina, 2010).

Conforme relato da professora Terezinha Nina, a prioridade de atendimento nas escolas de rede oficial seria para crianças de baixo nível socioeconômico, com idade de 04 a 06 anos. Além desse atendimento, crianças de 0 a 3 anos também eram atendidas na Creche Marise Castiel ${ }^{12}$, que foi construída no governo de Jorge Teixeira de Oliveira para atender os filhos de funcionários do Estado, e tinha toda estrutura adequada às sua finalidades: banheiras, berçários, etc. Conforme Terezinha Nina, o atendimento convencional era todo da rede territorial/estadual, e não havia esse atendimento pela prefeitura:

Este era o Atendimento chamado Convencional da Rede Estadual, em Porto Velho, onde as crianças eram atendidas em prédios especificamente construídos com esta finalidade, sendo as escolas:

- Jardim de Infância Branca de Neve - 1972;

- Jardim de Infância Casa de Davi - 1978;

- Creche Santa Marcelina - 1978;

- Jardim de Infância Domingos Sávio, posteriormente denominado de Pinóquio;

- Creche Marise Castiel - 1984. (Relato Profa. Teresinha Nina, 2010).

Conforme relato da professora, o atendimento não convencional, que sob o olhar de hoje não passou de um atendimento pobre para pobre, era o atendimento dado a um maior número de crianças na faixa etária de 04 a 06 anos, localizado nas periferias urbanas, utilizando e adaptando espaços físicos ociosos na comunidade, como: igrejas, escolas, clubes, etc. Como os recursos humanos e financeiros para garantir o atendimento eram insuficientes a comunidade era chamada a colaborar na confecção da merenda, limpeza da sala e desenvolvimento de atividades recreativas.

Adotaria uma metodologia flexível dando ênfase à criatividade da criança, proporcionando diferentes situações de interação social, enriquecendo assim seu desenvolvimento. Esse atendimento não Convencional era realizado nas Unidades Escolares de $1^{\circ}$ e $2^{\circ}$ Graus em forma de Galpões, Chapéus de Palha e ou espaços ociosos. Dentre elas, algumas foram: Escola de $1^{\circ}$ Grau Sebastiana Lima de Oliveira; Escola de $1^{\circ}$ Grau Jesus Bulamarqui; Escola de $1^{\circ}$ Grau Franklin Roosevelt; Escola de $1^{\circ}$ Grau Vilagram Cabrita; Escola de $1^{\circ}$ Grau Petrônio Barcelos; Escola de $1^{\circ}$ Grau Bela Vista; Escola de $1^{\circ}$ Grau Juscelino Kubistchek; Escola de $1^{\circ}$ Grau Risoleta Neves; Escola de $1^{\circ}$ Grau Rio Branco; Escola de $1^{\circ}$ Grau Manaus; Igreja São João Bosco; Igreja São José; Igreja Nossa Senhora do Amparo; Igreja BomJesus; Igreja Divino 
Espírito Santo; Igreja Nossa Senhora das Graças; Igreja Nossa Senhora Aparecida; Igreja São Sebastião; Igreja Sagrado Coração de Jesus; Centros Sociais do Bairro Mocambo; Centros Sociais do Bairro Embratel. (Relato Profa. Teresinha Nina, 2010).

Esse tipo de atendimento relatado não ocorria de forma isolada, mas era um movimento nacional com total influência no Território/Estado.

A professora destaca que nos locais onde o número de crianças por professor excedia a 30, recomendou-se a presença de um auxiliar que poderia ser: Aluno de $7^{\mathrm{a}}$ e $8^{\mathrm{a}}$ série - voluntário; Aluno de $2^{\circ}$ grau (hoje Ensino Médio) magistério - voluntário; Mãe de criança matriculada - voluntária. Também, visando expandir o atendimento, para cumprir o que propunha quanto à expansão, a SEDUC/RO realizava ainda compra de vagas nas escolas particulares de Educação Infantil estando de acordo com a Resolução $\mathrm{n}^{\circ}$ 012/CTERO/80, que na época fixava diretrizes para concessão de amparo técnico e financeiro a entidades particulares de ensino. Destacamos que essa prática de compra de vagas ainda é uma realidade dos dias atuais. Essas vagas eram destinadas a atender alunos carentes que morassem nos bairros onde havia estas escolas.

A composição das turmas era feita de acordo com a idade da criança assim classificada: creche - crianças de 0 a 1 ano; maternal - crianças de 02 a 03 anos; jardim de infância - crianças de 04 a 06 anos. Os jardins de Infância classificavam-se em períodos: $1^{\circ}$ Período - Crianças com 04 anos completos; $2^{\circ}$ período - Crianças com 05 anos completos ou a completar até 30 de junho; $3^{\circ}$ período - Crianças de 06 anos ou a completar até 30 de junho. As crianças com 07 anos ou a completar até 30 de junho ingressavam na $1^{\text {a }}$ série. Recomendava-se a formação de turmas de $1^{\text {a }}$ série com crianças essencialmente proveniente do PréEscolar. (Relato Profa. Teresinha Nina, 2010).

Nota-se que a omissão Estado brasileiro oferta minimamente adequada da educação escolar. Uma das saídas encontradas no período não difere muito das proposições liberais: utilizava-se da terceirização e da filantropia dos serviços educacionais para atendimento das camadas populares. A professora Terezinha Nina discorreu também sobre a organização pedagógica das pré-escolas:

O recreio era desenvolvido no período mínimo de 30 minutos, diariamente com a presença da professora, auxiliares ou mães. Nas escolas de $1^{\circ}$ grau, onde funcionavam salas anexas de pré-escola, o recreio era em horário diferente do recreio das outras séries. A promoção da criança Pré-Escolar era feita automaticamente ao final do ano letivo. A direção ou Professora expedia um documento (Declaração ou Certificado) aos alunos de 06 anos que se matriculariam na $1^{\mathrm{a}}$ série das escolas da Rede Oficial. (Relato Profa. Teresinha Nina, 2010).

Sobre a formação continuada das professoras e o acompanhamento técnicopedagógico, Terezinha Nina relata que:

As Escolas de Educação Infantil recebiam acompanhamento técnicopedagógico através de planejamento, avaliação, fichas, reuniões mensais, treinamentos semestrais ou anuais, visitas sistemáticas e periódicas por parte da SEDUC. A Supervisão em nível central encaminhava documentos que norteariam as Secretarias Municipais de Educação e Cultura (SEMEC's) na execução de suas atividades. A assistência técnica 
da SEDUC à equipe de supervisoras das SEMEC's era feita através de treinamentos, encontros, reuniões, visitas, observação de sala de aula, orientação quanto a confecção dos Planos de Curso e de Aula e do material didático. (Relato Profa. Teresinha Nina, 2010).

Lembra que foram coordenadores da Educação Infantil, em nível Estadual, no período de 1980 a 1994 as professoras: 1980/1981 - Professora Maria Augusta Lari; 1982 Professora Maria José Serrati; 1983/1985 - Professora Claudete Maria Cardoso Ferreira; 1985/1994 - Professora Terezinha Nina Paes, e; 1995/1998 - Elmeri Borges de Lima. Conforme Terezinha Nina:

A partir de 1982, o MOBRAL, que era vinculado a SEPS/MEC, teve a
participação ativa, apoiando a SEDUC nos programas de Educação Pré-
Escolar. Era uma atividade complementar e relevante, pois reforçava as
ações realizadas por outras entidades e atendia as áreas não cobertas pelas
demais instituições, sempre em consonância com as instruções da
SEDUC. O atendimento do MOBRAL tinha como objetivo orientar as
comunidades para a importância da Educação Pré-Escolar; contribuir na
integração com os sistemas de ensino, as entidades e as comunidades;
orientar a instalação e manutenção das condições de funcionamento dos
núcleos Pré-escolares. A LBA também executava atividade junto a
SEDUC no atendimento às crianças de 04 a 06 anos, fornecendo recursos
financeiros para aquisição de parte de gêneros alimentícios, merenda e
almoço escolar, e a Fundação de Assistência ao Estudante (FAE) fornecia
outros gêneros e material didático que complementavam o atendimento às
crianças nesta faixa etária. (Relato Profa. Teresinha Nina, 2010).

Ainda conforme Terezinha Nina, a Secretaria de Trabalho e Ação Social executava junto à SEDUC programas de prevenção à marginalização do menor, incluindo neste programa um Projeto Nutricional, médico e odontológico ao Pré-escolar na faixa etária de 03 a 06 anos e tinha como objetivo a socialização e a promoção da criança e da família carente. Ressalta ainda o trabalho realizado na área de Educação Infantil pelo SESC e SESI, atendendo crianças Pré-Escolares dependentes de comerciários de Porto Velho e destinando $40 \%$ das vagas às crianças carentes da comunidade e que não eram filhas de comerciários.

\section{Relato 2 - Elmeri Borges de Lima}

Elmeri Borges de Lima, cujo relato foi colhido em setembro de 2009, professora que atuou na Educação Infantil da SEDUC desde o início dos anos de 1970 até o ano de 1998, relata que na década de 1970, ainda Território Federal de Rondônia, a educação infantil denominava-se pré-escolar e atendia somente crianças na faixa etária de 4 a 6 anos. Assim como no Relato 1, ela lembra que em 14 de abril de 1972 foi construída a escola pública estadual denominada Jardim de Infância Branca de Neve, no bairro Arigolândia. Esta escola representa um marco na história do atendimento público às crianças pequenas em Rondônia, e em Porto Velho, já que somente nesse momento houve uma preocupação também com o espaço físico, o que o diferenciava dos atendimentos anteriores, em que era realizado junto às demais etapas da, hoje, educação básica. Em 1972, portanto, a Educação Infantil ficou oficialmente instituída na rede pública do Sistema Estadual de Ensino.

Ainda conforme Elmeri, em 1978 foi construída mais uma escola, o Jardim de Infância Casa de Davi, no bairro Meu Pedacinho de Chão, também em Porto Velho, com 05 salas de aula, oferecendo 300 vagas anuais. Outra creche concluída neste ano foi a 
Creche Santa Marcelina, também no bairro Meu Pedacinho de Chão, que iniciou atendendo 50 crianças. Ainda nessa década foram criadas salas anexas em escolas de ensino fundamental (na época $1^{\circ} \mathrm{Grau}$ ) para atender turmas de crianças com seis anos de idade.

É possível observar (Quadro 2) que Rondônia acompanhou a perspectiva nacional, pois do final dos anos de 1970 em diante o Estado contou com uma maior expansão de matrículas, também devido a outros modelos "não-formais", apoiados em recursos improvisados, tanto físicos, materiais, pedagógicos como de mão-de-obra.

Como exemplo, registra-se a presença da Fundação Brasileira de Assistência (LBA), que em de 1979, e em parceria com vários outros órgãos, inclusive com a Secretaria Municipal de Educação de Porto Velho, implantou nos municípios o "Projeto Casulo", objetivando atender crianças com idade entre 4 e 6 anos. Embora houvesse a preocupação com o aspecto educacional nos fundamentos do órgão, seu objetivo principal era a assistência e a meta seria atender um maior número de crianças, utilizando poucos recursos financeiros. Também tinha a intenção de evitar a marginalização das crianças e possibilitar às mães tempo livre para trabalhar e contribuir com a renda familiar. O projeto atendeu a 1.758 crianças em todo o Estado. (RONDÔNIA, 1997).

Conforme Elmeri, no final dos anos de 1970 a Prefeitura Municipal de Porto Velho executou o Projeto Casulo, com quatro turmas em salas anexas às escolas Municipais Antônio Ferreira da Silva e Padre Chiquinho. Em 1980, visando a organização da educação pré-escolar, a Secretaria de Educação do Território Federal de Rondônia criou, através da Portaria Ministerial n 168 de 26/11/1980, a Divisão de Educação Pré-Escolar, vinculada ao Departamento de Ensino. Em 1981, seguindo a linha da assistência, foi implantado o Projeto de Atendimento Informal ao Pré-Escolar de Rondônia (PROAPRO), que consistia em aproveitar espaços ociosos, equipamentos e materiais existentes na comunidade, o que o caracterizava ser de baixo custo.

O PROAPRO, visando "atender" o maior número de crianças, organizava turmas compostas por 100 alunos cada, entre 04 e 06 anos, com duas professoras também por turma. Adotava uma metodologia flexível, enfatizava a criatividade da criança e experiências que favorecessem seu desenvolvimento. Esse projeto foi desenvolvido no Estado até o ano de 1982, quando o atendimento voltou a ser feito em salas comuns, com crianças da mesma faixa etária, transformando-se em Unidades Específicas de Jardins de Infância. (RONDÔNIA, 1997).

Elmeri considera que o projeto propiciou um significativo aumento numérico no atendimento à clientela atendida pela rede estadual, pois o mesmo funcionava em espaços diversos como centros comunitários, igrejas, galpões de associações ou clubes, além de outros locais. Com isso, segundo ela, o número de crianças atendidas aumentou visivelmente, tendo sido contratado um significativo número de docentes para esse fim, os quais foram selecionados e capacitados.

Observamos que, de fato, é provável que em um dado momento de carência total algo precisaria ser feito, mas isso não isenta o Estado brasileiro da responsabilidade pela falta de políticas ou pelas precárias ações implementadas.

Ainda sobre esse período, a professora Elmeri diz que:

[...] as dificuldades junto à Secretaria de Educação, na época, eram a escassez de verbas, a capacitação de professoras que anualmente recebiam treinamento e logo em seguida eram convidadas a trabalhar nas escolas particulares com algumas vantagens, ficando as escolas do Governo sempre com pessoal despreparado. (Relato Profa. Elmeri, 2009). 
O quadro de pessoal docente era precário e sobre o restrito atendimento e a formação dos professores e das professoras, a professora Elmeri destaca:

Naturalmente, o atendimento não alcançava a demanda; as professoras eram formadas em nível de $2^{\circ} \mathrm{Grau} /$ magistério e algumas em nível de $1^{\circ}$ grau; não tínhamos ninguém com especialização e o trabalho de orientação pedagógica era realizado através de reuniões semanais na própria escola com auxílio de professoras com um pouco mais de experiência, oriundas de outros Estados da Federação que vinham residir em Porto Velho. (Relato Profa. Elmeri, 2009).

Em meados da década de 1980, quando Rondônia já havia passado à condição de Estado, a SEDUC passou a capacitar professores e professoras nos municípios do interior. Para isso, a estratégia consistia em deslocar técnicas da secretaria até os municípios para fazerem a capacitação com os professores e professoras de educação infantil, ou, o que também ocorria, as professoras e professores virem a Porto Velho receber algum tipo de capacitação.

Nos anos de 1980 a SEDUC, segundo a professora Elmeri, começou a elaborar documentos, cadernos, apostilas pedagógicas, bem como iniciou um trabalho de supervisão às escolas de educação infantil. Para a professora, esse foi um período de grande atividade em prol do desenvolvimento da educação pré-escolar.

A professora corrobora a informação já destacada no relato 1 , informando que também contribuíram com a expansão do atendimento às crianças de 0 a 6 anos, outras instituições de setores privados que implantaram o atendimento Pré-Escolar, como por exemplo, o Serviço Social do Comércio/SESC (que iniciou suas primeiras atividades, atendendo crianças de três a seis anos: em 1977 com uma sala de aula e em 1978 ampliou esse atendimento para quatro, tendo em 2009 sete salas de aula) e o Serviço Social da Indústria/SESI, ambos atendendo dependentes dos beneficiários desses segmentos atuantes no Município de Porto Velho.

\section{Relato 3 - Josélia Gomes Neves}

Josélia Gomes Neves, que nos concedeu esse relato em 2009, foi professora na educação infantil e também atuou como técnica na Secretaria Estadual de Educação (SEDUC) no período de 1988 a 1991, e na Secretaria Municipal de Educação (SEMED) de Porto Velho no ano de 1993 e início de 1994, lembra que os cursos de formação para o magistério nunca tiveram a preocupação de preparar as professoras para a educação infantil. A formação considerava apenas as séries iniciais do ensino fundamental (na época, primário). Sua fala denuncia a distância que havia entre a formação e a realidade social, o que implicava em conhecimentos pedagógicos mais específicos para atuar com crianças menores de sete anos e também em escolas de periferia que atendiam aos cidadãos e cidadãs reais. No entanto, tal realidade de certa forma não era uma especificidade de Rondônia, mas característica histórica da formação docente no Brasil.

As escolas de formação docente (Institutos de Educação) em nível médio (magistério) de modo geral tinham anexos onde funcionavam as turmas das séries iniciais, local da formação prática das alunas e alunos dos Institutos. Tais anexos eram, conforme as condições da época, melhor equipados e o estágio desenvolvido em condições ideais e possíveis, embora somente naquele contexto. A realidade sociocultural e econômica não era contemplada na formação docente.

Em Porto Velho, o Instituto de Educação Carmela Dutra, que formava professoras para o magistério das séries iniciais, também possuía um anexo com essa finalidade. O que 
na época era considerado o ideal de formação, hoje já olhamos com muitas críticas pela característica pouco realista dos mesmos. Sobre essa questão, diz a professora Josélia:

Comecei o trabalho e era muito diferente da concepção de escola, da concepção de aluno que eu tinha. Tanto da escola que eu frequentei como da escola que eu fiz estágio, no Homerinho, um anexo do Carmela Dutra. Eram crianças de camadas populares, crianças que muitas vezes a roupa que vinham durante a semana era aquela roupinha mesmo, bem surrada. Foi uma experiência interessante. Eu não tinha formação. A minha formação estava voltada [...] para os anos iniciais do ensino fundamental, do magistério que estudei, e não lembrava de nenhum tipo de formação para o pré-escolar. [..] comecei a procurar, a ir atrás de livros [...] foi aí que começou meu processo formativo. Comecei a devorar material sobre educação infantil. (Relato Profa. Josélia, 2009).

Percebemos na fala da professora que a realidade criava a necessidade de formação em serviço, que era também muito precária, o que contribuía para a desvalorização da atividade docente.

Nesse sentido a professora Josélia Gomes Neves, relatando sobre sua atuação como professora na educação infantil, pela Secretaria Municipal de Educação, em 1986, destaca o momento em que foi assumir uma sala de aula em uma escola da rede municipal. A professora comenta que:

Quando cheguei descobri que era na verdade uma escola comunitária, no bairro São Sebastião II, que era pobre, bairro de periferia, onde as pessoas eram extremamente maltratadas porque não tinha nem ruas; [...] fui trabalhar com o pré-escolar. [...] a comunidade entendia que também tinha direito à educação e construiu, de forma muito rudimentar, dois compartimentos separados e decidiram que seriam duas salas de aula. (Relato Profa. Josélia, 2009).

Fica evidente na fala da professora o que as duas professoras anteriores destacaram: o baixo atendimento à educação infantil era realizado pelo Território/Estado. $\mathrm{Na}$ rede municipal o atendimento era precário e até aquele momento (final dos anos de 1980) não havia escolas específicas para essa etapa.

A professora lembra que era muito comum as comunidades criarem as escolas comunitárias. Uma razão visível e imediata de tais escolas seria a resolução dos problemas também imediatos como a falta de escolas públicas, porém isso acabava por provocar o setor público a prestar algum tipo de atendimento, o que ocorria, mas geralmente de forma também muito precária.

Em 1993 Josélia Gomes Neves foi convidada para assumir a Divisão de Ensino Pré-Escolar (DIEPE), na Secretaria Municipal de Educação, e faz um relato de como se encontrava o atendimento à Educação Infantil pela rede municipal naquela época. A professora comenta sobre o início da gestão, em 1993:

Em 1992 houve eleição e foi eleito José Guedes para prefeito. Roberto Sobrinho, que era o presidente do sindicato na época, foi convidado para assumir essa Secretaria de Educação e [...] me convidou para eu trabalhar na Educação Infantil que era na época educação Pré-escolar que a gente chamava. [...] assumi em fevereiro de 1993 essa Divisão e aí convidei algumas colegas que eu já conhecia: a Leiryvanda, Laura Heloísa, a Maracélia, a Socorro, para trabalharem comigo nessa Divisão. (Relato Profa. Josélia, 2009). 
O atendimento era realizado predominantemente através das escolas comunitárias, em precárias condições, e pelas casas-creches, chamadas de atendimento das Mães Crecheiras:

A gente contava nos dedos quantas escolas de educação infantil existiam. $\mathrm{O}$ que a gente tinha era muito parecido com o Estado. A gente tinha escola [de ensino fundamental] com salas de educação infantil. Então a gente tinha escolas com duas salas, o que era mais comum nessa época. Tinha na Escola Pe. Chiquinho um chapeuzinho de palha; na Escola Antônio Ferreira duas salas [...] na Escola Joaquim Vicente Rondon quatro salas. Então era o que existia; não tinha essa coisa assim um jardim de infância ou a escola de educação infantil na prefeitura. O que tinha era uma demanda muito grande. Então quando nós chegamos lá o atendimento da prefeitura era uma coisa assim, mixuruca, era mínimo o que acontecia. [...] isso era 1993; quem tinha tradição, quem acumulou maior trabalho foi o Estado. Ele tinha os Jardins de Infância Branca de Neve, Pinóquio, Casa de David. O Estado tinha escolas específicas, a prefeitura não tinha. E aí eu lembro que [...] nós tínhamos uma demanda inicial. $\mathrm{O}$ que era que a gente ia fazer com essas escolas comunitárias? Elas não poderiam expedir nenhuma documentação, então o que elas faziam? Educação Infantil, pois não tinham que cobrar nenhum documento de educação infantil. (Relato Profa. Josélia, 2009).

A demanda por Educação Infantil encontrada e as pressões da comunidade com a ajuda de arranjos políticos eram visíveis, segundo a professora:

E aí, o que chegou para nós? Chegou cada vez mais uma pressão por educação infantil. As associações de bairros, principalmente algumas associações de mulheres da zona leste, que era um dos lugares mais pobres que tinha, começaram a se organizar e a defender a educação infantil, a pré-escola. Mas como eles defendiam? Eles queriam que a prefeitura encaminhasse a merenda, material de limpeza, material de consumo para o aluno, a cartolina, o papel, o mimeógrafo; e eles pediam a contratação de monitor. Por quê? Porque o prefeito anterior tinha instituído um concurso para monitor, aí a prefeitura chamava aquele monte de monitor, todo mundo já estava trabalhando e o que acontece, a prefeitura podia chamar mais certa quantidade de serviços prestados. Então o que acontecia: o presidente da associação de bairro dizia: eu quero essa listinha de material de consumo, eu quero material de limpeza, eu quero merenda e quero que você contrate o meu filho, o meu sobrinho, e aí você ia olhar a pessoa e raramente ela tinha o ensino médio; às vezes ela tinha $6^{\mathrm{a}}$ ou $7^{\mathrm{a}}$ série. (Relato Profa. Josélia, 2009).

Conforme a professora, a saída encontrada pela SEMED foi começar a organizar, sem desconsiderar as reais necessidades, mas primando pela melhoria:

Quando nós brecamos a gente dizia assim: você pode até trazer alguém da comunidade, mas tem que ter magistério. Aos poucos nós começamos a discutir com a comunidade para que a escola fosse assumida pela prefeitura.

[...]. Agora nós tínhamos outro problema: as chamadas escolas comunitárias tinham um quadro de precariedade geral e eram todas na área de educação infantil. Teve um tempo que a gente tinha 103 escolas comunitárias, todas de educação infantil. [...]. Era um quadro de 
precariedade. Primeiro: a formação - quem ia dar aula ou era monitor ou era um voluntário, este com contrato emergencial; segundo: o espaço onde essas crianças estudavam eram aqueles espaços adaptados, horríveis. Espaços muitas vezes fechados, sem ar, era um negócio, assim, pavoroso. De alguns a gente ficava deprimida quando voltava. A questão da merenda era complicada. (Relato Profa. Josélia, 2009).

Algumas melhorias implementadas, segundo a professora, foram: a exigência de docentes com magistério, organização das escolas em polos para o desenvolvimento de formação continuada, e qualidade do material de consumo para a educação infantil.

Fomos numa discussão em São Paulo e fomos ao Rio Grande do Sul para fechar algumas coisas do Projeto Escola Viva e umas das coisas que nós nos aproximamos muito, em São Paulo, foi do programa de formação permanente, que era ainda um trabalho que o Paulo Freire tinha começado na gestão da Luiza Erundina, com a formação permanente. $\mathrm{Na}$ educação infantil, quando nós assumimos as comunitárias, a gente viu que era um trabalho da maior importância porque as pessoas que iam ali iam extremamente despreparadas. Nós investimos em formação continuada. Como a gente fazia: todo mês tinha um grande encontro. A gente separou, organizou a cidade por zonas. A gente começou a qualificar a questão: quem vai para a educação infantil não pode ser qualquer pessoa. Deveria ter, pelo menos, o magistério; segundo ponto: a questão da formação permanente que a gente começou a fazer, porque a maioria, igual a mim, que tinha formação em magistério, mas tinha pouca discussão acumulada sobre o que era o trabalho docente com a educação infantil. E outra que nós começamos a fazer: melhorar a qualidade do material pedagógico. Fornecedor chegava com material de $5^{\mathrm{a}}$, voltava. Material da educação infantil tinha que ser o melhor material. (Relato Profa. Josélia, 2009).

Porém, segundo a professora Josélia, a grande surpresa para o prefeito, secretário de educação e para ela mesma, foi que direcionaram todo um investimento para a melhoria do atendimento, também iniciaram o atendimento em muitas escolas comunitárias que iam aparecendo e, quando foram fazer os cálculos, não haviam ampliado uma só matrícula.

$\mathrm{Ou}$ seja, todos aqueles alunos e alunas das escolas comunitárias eram contabilizados, mas até então, não eram atendidos pela rede municipal. Foram investigar e descobriram que o atendimento era feito assim: quando sobrava merenda ou qualquer outro material as escolas comunitárias recebiam, mas independente disso, eram contabilizadas como alunos da rede municipal, o que, segundo ela, foi uma situação constrangedora para a gestão:

Uma coisa que deixou todo mundo triste: nós achamos que tínhamos ampliado o atendimento. Do ponto de vista da gestão foi problemático porque se você está qualificando e o número não aumenta parece que não se fez nada. Nossa! Foi muito enrolado, foi muito complicado administrar isso. Só que, como era de professores e professoras e a gente já vinha discutindo a coisa da qualidade para a escola pública, não foi tão difícil, mas a gente sentia um mal-estar [...].(Relato Profa. Josélia, 2009).

Em 1996, ao término daquela gestão, a SEMED contava com 6 (seis) escolas para atender exclusivamente à Educação Infantil: Jardim de Infância Ulisses Soares Ferreira, Jardim de Infância Pe. Geovane Mendes, Jardim de Infância Meu Pequeno Jones, Jardim 
de Infância São Miguel, Creche Chapeuzinho Vermelho e Jardim de Infância Saul Bennesby. Estas seis escolas, com exceção do Jardim de Infância Saul Bennesby, foram construídas nos anos de 1992 a1996. A Escola de Ensino Fundamental Bom Princípio também funcionando desde 1992, no período de 1994 até 1996 atendeu somente à Educação Infantil ${ }^{13}$.

Em 1997 foi criada em Jaci-Paraná, distrito de Porto Velho, a Escola de Educação Infantil Joaquim Vicente Rondon, mas que em 1998 já deixou de ser exclusiva dessa etapa passando a atender também o ensino fundamental.

No período de 1997 a 2004 nenhuma escola exclusiva de educação infantil foi criada. Houve, sim, um movimento inverso: as escolas que atendiam somente a educação infantil, criadas no período de 1991 a 1996, passaram, por meio de Decretos, a atender também ao ensino fundamental.

De 2000 ao início de 2004 não havia na SEMED escola exclusiva de Educação Infantil, ou seja, todas eram "Escola Municipal de Educação Infantil e Ensino Fundamental" (EMEIEF).

Mesmo a LDB n 9.394/96, no artigo 98, fixando o prazo de três anos a partir de sua publicação, para que as creches fossem integradas aos sistemas de ensino, foi somente no ano de 2004 que a prefeitura do Município de Porto Velho legalizou essa situação, através do Decreto $n^{\circ}$. 9.432/2004 de 16 de junho de 2004 .

Por força desse Decreto o prefeito remanejou da estrutura organizacional da Secretaria Municipal de Ação Comunitária (SEMAC) para a estrutura organizacional da Secretaria Municipal de Educação (SEMED), as creches municipais Alegria e Moranguinho, e as creches comunitárias: Creche Areal da Floresta, Dr. Tancredo Neves, Cidade do Lobo e Jardim Eldorado, até então atendidas pela SEMAC. No período de 1999 a 2004, mesmo com instrumentos jurídicos garantindo o direito à educação infantil, a evolução foi bem pequena: o atendimento à creche subiu de 4 para 6 escolas, e a préescola, no mesmo período, subiu de 17 para 25 escolas.

\section{CONSIDERAÇOES FINAIS}

A análise dos dados organizados a partir de documentos bem como dos relatos das professoras nos possibilitou observar que o período anterior aos anos de 1990 é marcado pela quase ausência de atendimento formal no município às crianças menores de sete anos. Tais evidências são apontadas nas vozes das professoras e nos dados extraídos das fontes documentais que, juntas fizeram emergir o que foi a realidade do atendimento à infância até aquele momento. $\mathrm{O}$ atendimento realizado ou era informal, sem o acompanhamento sistematizado dos órgãos oficiais ou realizado pela rede pública estadual, mas, neste caso, a partir dos anos de 1970.

De modo geral foi possível perceber que o atendimento a educação infantil da década de 1970 ao início dos anos de 1980 pela rede particular superava, em termos quantitativos, o atendimento público. O Estado de Rondônia não foi tão presente em termos de políticas voltadas para a infância e educação infantil, embora devamos reconhecer que o atendimento formal a essa etapa foi iniciado pela rede territorial e posteriormente estadual de ensino.

Outro fato é que, se o atendimento à infância foi insignificante do ponto de vista numérico, igualmente o foi no aspecto qualidade. No entanto, essa ausência de políticas e ações voltadas para a infância não foi característica apenas de Rondônia ou de Porto Velho, nesse período. Nacionalmente a infância timidamente aparecia em programas e 
ações sociais financiáveis e, os programas que existiam eram voltados apenas para a assistência. (BARRETO, 2003).

Os dados de matrícula apresentados no período estudado confirmam as falas das professoras colaboradoras no que se refere à quase inexistência de atendimento educacional à etapa da educação infantil. Ressalta-se, no entanto, que até 1988 a educação infantil ainda não era colocada enquanto direito constitucional o que não justifica, mas de alguma forma explica a não priorização desse atendimento. No município de Porto Velho, como vimos, a educação infantil foi colocada como direito na Lei Orgânica de 1990 e foi justamente a partir daí que se começou a pensar nesse atendimento formal, conforme evidenciaram os dados.

Outro fato é que do início de 1990 até meados dessa década, essa etapa começou a se expandir na rede municipal. A prefeitura começou definir e ampliar uma rede de escolas de educação infantil, com construção de rede física e ampliação do atendimento institucionalizado e gratuito, processo que retrocedeu a partir de 1998 quando as escolas de educação infantil foram novamente denominadas como sendo de educação infantil e ensino fundamental. Ou seja: em lugar de continuar com a política de ampliação ou, no mínimo, de manutenção, houve um retrocesso no atendimento em razão, principalmente, do novo modelo de financiamento do ensino fundamental com a criação do Fundo de Manutenção e Desenvolvimento do Ensino Fundamental e de Valorização do Magistério (FUNDEF).

Destacamos que em todos os tempos há sempre pessoas preocupadas e, sem dúvida, são elas que promovem a mudança e impulsionam a transformação da sociedade. Com a educação infantil não foi diferente: pessoas movimentaram-se para que tivéssemos alguns avanços no atendimento, que, longe de ser o ideal, reconhece-se que a infância, em termos de educação infantil escolar, já teve dias piores.

Por fim, mesmo cientes dos limites de um estudo com registros históricos, esperamos ter contribuído com dados sobre o atendimento institucionalizado, e pelo poder público, à educação infantil no município de Porto Velho.

\section{REFERÊNCIAS}

BARRETO, A. M. R. F. A educação infantil no contexto das políticas públicas. Revista Brasileira de Educação. São Paulo: nº 24, Set /Out /Nov /Dez, 2003, p. 53-65.

BRASIL. Congresso Nacional. Constituição Federal da República Federativa do Brasil. Brasília: Senado Federal, Centro Gráfico, 1988.

BRASIL. Congresso Nacional. Lei de Diretrizes e Bases da Educação Nacional.Lei $\mathbf{n}^{\mathbf{0}}$ 9.394/96, de 20 de dezembro de 1996. Diário Oficial da União, Brasília, 23 de dezembro de 1996.

BRASIL.INEP. Censo Escolar. Disponível em: <www.fgv.br/cps>. Acesso em 05/11/2006.

BRASIL. IBGE. Biblioteca. Disponível em: <www.Ibge.Gov.br>. Acesso em: 22 de novembro de 2008.

BRASIL. IBGE. Contagem da População 2007. IBGE. Brasília: 2007. Disponível em: <www.Ibge.Gov.br>. Acesso em: 22 de novembro de 2008.

CAMPOS M. M. M.; COELHO, Rita de Cássia; CRUZ, Silvia H. Vieira. Consulta sobre qualidade da educação infantil: relatório técnico final. São Paulo: FCC/DPE, 2006. 
CASTIEL, S. M. M. C. Raízes de Rondônia. Porto Velho: Centro Gráfico do Senado Federal, 1990.

DECCA, Edgar Salvadori de. Questões teórico-metodológicas da história. In SAVIANI, Demerval: LOMBARDI, José Claudinei: SANFELICE, José Luis (Orgs.). História e História da Educação. Campinas, SP: Autores Associados, 1998.

DIEGUES, A. C. (Org.). Desmatamento e modos de vida na Amazônia. São Paulo: NUPAUB, 1999.

GALEANO, E. As veias abertas da América Latina. 45. ed. Trad. Galeano de Freitas. São Paulo: Paz e Terra, 2005.

GOMES, P. de A. A educação escolar no Território Federal do Guaporé (1943-1956). 2007. Mato Grosso: 148f.Dissertação (Mestrado) -Pós-Graduação em Educação. Universidade Federal de Mato Grosso, Cuiabá, 2007.

HUGO, V. Desbravadores. Rio de Janeiro-RJ: Companhia Brasileira de Artes Gráficas, 1991. V. I e II.

KRAMER, S. A Política do pré-escolar no Brasil: a arte do disfarce. São Paulo: Cortez, 1992.

KUHLMANN Jr. Infância e Educação Infantil: uma abordagem histórica. Porto Alegre: Mediação, 1998.

LIMA, A. M. de. Achegas para a história da Educação no Estado de Rondônia. Secretaria Municipal de Educação e Cultura. Porto Velho: Gráfica da Prefeitura, 1987.

LIMA, A. M. de..Terras de Rondônia: aspectos físicos e humanos do Estado de Rondônia. 3. ed. Porto Velho: OFF-7 Editora Gráfica Ltda,1998.

MATIAS, F. Porto Velho no contexto de Rondônia. 2007. <http://www.estadaodonorte.com.br/canal>. Acesso em 29-08-2009.

MATIAS, Francisco. Pioneiros: Ocupação Humana e Trajetória Política de Rondônia. Porto Velho: Maia, 1998.

MEDEIROS, E. L. A Historia da Evolução Sócio-Política de Rondônia. Porto Velho: Rondoforms Editora e Gráfica Ltda, 2004.

MEIRELES, D. M. Populações indígenas e a ocupação de Rondônia. 1983. 141f. Monografia (Graduação) - Departamento de História, Fundação Universidade Federal de Mato Grosso, Cuiabá, 1983.

PACÍfICO, J. M. Políticas públicas para a Educação Infantil em Porto Velho/RO (1999/2008). 2010. 358f. Tese (Doutorado em Educação Escolar) - Faculdade de Ciências e Letras de Araraquara, Universidade Estadual Paulista, Araraquara, SP, 2010.

RONDÔNIA. SEDUC. Diretrizes para a Educação Infantil: estrutura, organização e funcionamento. Porto Velho: SEDUC, 1997.

ROSEMBERG, F. Simpósio Educação Infantil: construindo o presente. Anais. Brasília: UNESCO, Brasil, 2003.

TAMBORIL, M. I. B. Aproveitamento escolar no ensino fundamental de Porto VelhoRO, 1990-1997. 2000. 160f. Dissertação. (Mestrado em Psicologia) - Instituto de Psicologia, Universidade de São Paulo, São Paulo, 2000. 
TEIXEIRA, M. A. D.; FONSECA, D. R. da. História Regional: Rondônia. 2. ed. Porto Velho: Rondoniana, 1998.

1 Doutora em Educação Escolar/UNESP - Fundação Universidade Federal de Rondônia. juracypacifico@unir.br

2 Doutor em História e Filosofia da Educação/UNICAMP - Universidade Federal de Rondônia. marcooliveiragomes@yahoo.com.br

${ }^{3}$ Castiel (1990), Lima (1998), Fonseca (1998), Hugo (1991), Teixeira (1998); Diegues (1999), Medeiros (2004), Galeano (2005), Gomes (2007) e Matias (1998; 2007).

${ }^{4}$ Este texto é parte da tese de doutorado intitulada "Políticas públicas para a Educação Infantil em Porto Velho/RO (1999/2008)", de autoria de Juracy Machado Pacífico, defendida em 2010 pela UNESP, com novas contribuições dos autores.

${ }^{5}$ Em 10 de abril de 1929 a cidade de Guajará-Mirim passou à condição de município. As primeiras escolas foram criadas por Monsenhor Francisco Xavier Rey (Dom Rey - Primeiro Bispo Prelazia). Antes dessa data não existiu qualquer tentativa por parte do setor público no sentido de organizar um sistema de ensino. Da mesma forma que em Porto Velho, quem tinha condições financeiras mandava os filhos e filhas estudar em outras cidades, como São Paulo, Rio de Janeiro, Belo Horizonte, e muitos eram mandados para a Europa, Estados Unidos o Oriente Médio: Líbano, Turquia, entre outros. (TEIXEIRA; FONSECA, 1998).

${ }^{6}$ Com essa reorganização a Divisão de Educação passou a ser constituída pelos seguintes órgãos: Turma da Administração; Secção de Ensino; Secção de Difusão Cultural; Secção de Assistência ao Escolar. Destacamos a Seçãa do Ensino que era composta pelos seguintes setores: Ensino Primário (pré-primário, elementar e complementar); Ensino Normal (formação de regentes do Ensino Primário e de Cursos de Aperfeiçoamento do Magistério); Ensino Supletivo (Curso de Alfabetização, Curso de Continuação Missões Pedagógicas Itinerantes; Ensino Profissionalizante (patronatos); e Ensino secundário.

${ }^{7}$ Em Rondônia existiam dois tipos de anexos: um funcionava junto às próprias escolas de ensino fundamental, ou fundamental e médio. O outro, evidenciando que esta situação ainda faz parte da realidade do atendimento no Brasil, e que não é caso apenas de Rondônia, funcionava aos moldes de que fala Maria Malta Campos, comentando sobre a pesquisa publicada com o título "Consulta sobre qualidade da educação infantil: relatório técnico final. (CAMPOS; COELHO; CRUZ, 2006, s.p).

${ }^{8}$ Destacam-se: a Constituição Federal de 1988 (e as Emendas Constitucionais 14/1996 e 53/2006), a LDB n ${ }^{\circ}$ 9.394/96 de 1996, que reorganiza o sistema educação no Brasil, a Lei no 9.424/1996 (Lei do FUNDEF), que regulamenta o financiamento para o Ensino Fundamental, e Lei 11.494/2007 de 20/06/2007 (Lei do FUNDEB), que regulamenta o financiamento para a Educação Básica.

${ }^{9}$ Homenagem ao Marechal Cândido Mariano da Silva Rondon que coordenou a abertura da BR 364, que liga Cuiabá a Porto Velho/RO.

${ }^{10}$ Porto Velho (a capital), Guajará-Mirim, Ariquemes, Jaru, Ouro Preto do Oeste, Ji-Paraná, Presidente Médici, Cacoal, Espigão do Oeste, Pimenta Bueno, Vilhena, Colorado do Oeste e Costa Marques.

${ }^{11}$ Disponível em www.ibge.gov.br/cidades. Contagem da população em 2007.

${ }^{12}$ A Escola de Pré-Escolar Professora Marise Castiel foi inaugurada no dia 12 de Abril de 1984. O nome da Creche, Professora Marise Castiel, é uma homenagem a uma educadora que dedicou sua vida ao magistério de Rondônia. Sua primeira Diretora foi a assistente social Sra. Maria das Graças Rabelo Paixão, tendo ao longo de 21 anos várias Diretoras onde destacamos as professoras Claudete Maria Cardoso, falecida em 1995, a Professora Vera Maria Barros e a Professora Anita Felix Fernandes. No início a Creche era subordinada a Associação dos Servidores públicos de Rondônia (ASPRON), e atendia 150 crianças, a partir de 1991, de acordo com o decreto $\mathrm{n}^{\circ} 5.230$ de agosto/91, ficou sobre responsabilidade da Secretaria de Estado da Educação - SEDUC. (Informações retiradas do Histórico da Escola).

${ }^{13}$ Ver dissertação de mestrado de Maria Ivonete Barbosa Tamboril, defendida em 2000/IP/USP/SP.

Recebido: $\quad$ set-13

Aprovado: out-14 